\title{
Self-assembling cyclic systems as drug carriers
}

\author{
A. Banerjee $\cdot$ A. Yadav
}

Received: 20 June 2012/ Accepted: 13 August 2012/Published online: 11 September 2012

(C) The Author(s) 2012. This article is published with open access at Springerlink.com

\begin{abstract}
Self-assembling cyclic systems have been of interest to researchers for over a decade now, and their wide variety applications have been explored from electronic devices to medicinal purposes. But still their discovery for newer innovative applications remains as valuable as before. In this study, ab initio Hartree-Fock molecular orbital calculations have been performed on peptidic and peptidomimetic cyclic compounds to identify characteristics required in compounds for efficient selfaggregation. The effect of these characteristics in determining the pore size and length of nanotube has been studied. Effect of backbone and substituents on environment of outer and inner surface and carriage properties has been studied in detail. Self-aggregating compounds (Ala) $)_{12}$ and (Ala) ${ }_{10}$ have been predicted to form a tubular structure with dimensions in nanoscale. They have been predicted to work as novel drug carriers having inert outer wall and inner pore. A peptidic self-aggregating compound (Ala) $)_{12}$ has been studied and suggested as carrier for antibiotic gentamicin to exemplify carriage properties of the designed compound. Such novel self-aggregatory systems are expected to help simplify the drug delivery process and increase bioavailability of various drugs.
\end{abstract}

Keywords Self-assembling - Cyclic systems · Drug delivery systems · Gentamicin · Drug carrier . Peptidic carriers · Peptidomimetic

A. Banerjee · A. Yadav ( $\square)$

Department of Chemistry, University Institute

of Engineering and Technology, CSJM University,

Kanpur 208024, India

e-mail: arpitayadav@yahoo.co.in; antaraemails@gmail.com

\section{Introduction}

Self-aggregating systems offer a variety of potential applications: from fabricating materials, to optoelectronics, to formation of nanotubes and drug delivery systems (Ahn et al. 2002; Jung 1999; Ijima 1991; Harada et al. 1993; Schnur 1993; Thess et al. 1996; Miyamoto et al. 1996).

Carbon nanotubes are also one such exciting example. These have been extensively studied experimentally as well as theoretically (Ahn et al. 2002; Hartgerink et al. 1996; Mintmire et al. 1992; Hamoda et al. 1992; Saito et al. 1992; White et al. 1993). These self-aggregated forms have also been used for carriage of various types of materials (Ebbesen and Ajayan 1992; Ajayan and Iijima 1993; Ajayan et al. 1993; Guerret-Piecourt et al. 1994; Dujardin et al. 1994; Loiseau and Pascard 1996).

Organic nanotubes have been synthesized by self-aggregation of cyclic peptides (Sloan et al. 1998; Ghadiri et al. 1993, 1994, 1995; Ghadiri 1995; Khazanovich et al. 1994). Recent studies have highlighted the use of these organic nanotubes as mimics of biological channels, molecular adapters for pore-forming proteins, transport vehicles in drug delivery systems and other nanostructural materials (Hartgerink et al. 1996; Kim et al. 1998; Fernandez-Lopez et al. 2001; Amorin et al. 2003; Brea et al. 2006; SanchezQuesada et al. 2000; Clark et al. 1998a, b; Horne et al. 2005; Ortiz-Acevedo et al. 2005; Schalley 2004; Ashkenasy and Ghadiri 2004). Recent work by Ghadiri et al. (1993) has highlighted the spontaneous self-assemblage of cyclic peptides having a flat ring-shaped conformation by controlled acidification of alkaline peptide solutions. The structures were made up of even number of alternating D-, L-amino acid residues. The rings were stacked together through hydrogenbonding interactions and formed a hollow tubular cylindrical structure in the nanoscale and hence called nanotubes.

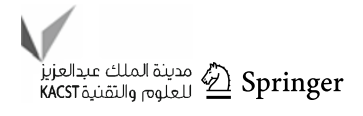


Figures 1 and 2 depict some usages of such self-aggregated systems. The interesting aspect is that the dimensions and properties can be tuned according to needs. Figure 1 describes self-assembling 6-8 residue peptides synthesized by Ghadiri and colleagues at Scripps Research Institute (Fernandez-Lopez et al. 2001; Ghadiri et al. 1993, 1994, 1995; Ghadiri 1995; Sanchez-Quesada et al. 2001). These peptides are capable of forming holes in bacterial membrane disrupting $\mathrm{t}$ asstacks lethal to bacteria. Figure 1 also depicts peptide-polymer hybrid nanotubes synthesized by Couet et al. (2005). The peptide nanotube in this case is embedded in a polymer shell. The structure and properties are determined by both peptide and polymer. The surfaceinduced polymerization around nanotube offers shapepersistent hybrid materials not easily accessed otherwise. Other research groups have also synthesized self-assembling cyclic peptides and studied their usage in liquid crystals and drug delivery systems (Tu and Tirrell 2004; Leclair et al. 2004). Figure 2 shows trapped solvent wire inside self-assembled cyclic peptide characterized by Raghavender et al. (2009). These aggregated cyclic peptides form pore across cell membrane which suggests their bactericidal property. Molecular dynamic simulations by Dehez and coworkers explain ion transport through these channels.

In this study, conditions for self-aggregation in cyclic systems have been explored keeping in mind their prospective usage in aggregated form. The properties of a cyclic self-aggregated peptide depend upon the backbone and type of substituents used (Ghadiri et al. 1993, 1994, 1995; Ghadiri 1995; Khazanovich et al. 1994; Kobayashi et al. 1995). However, changes in stacking behavior with slight change in backbone and number of residues have not been clearly understood.

\section{Methods}

$\mathrm{Ab}$ initio molecular orbital (MO) calculations have been performed at the Hartree-Fock level utilizing 6-31G basis set on some large peptidic and peptidomimetic cyclic compounds to explore and subsequently highlight their usage for medicinal purposes. Complete geometry optimizations were performed on the monomer and dimer of the cyclic compounds with a steepest descent approach utilizing redundant internal coordinates (Peng et al. 1996; Peng and Schlegel 1994). For convergence the rms of forces was required to be less than $3 \times 10^{-4}$. Potential energy of the system is minimized with respect to all bond lengths, bond angles and dihedral angles. Stationary points corresponding to low-energy conformations were obtained using GAUSSIAN'03 (Frisch et al. 2004) and viewed using GAUSSVIEW (Dennington et al. 2003).
Self-aggregating tendency of cyclic peptidomimetic compounds was studied by intermolecular interaction calculations with and without basis set superposition error (BSSE) estimate. Compounds were stacked over one another keeping in mind optimum conditions observed for stacking. Covalent bonding between two compounds was prohibited. At each step of stacking, stacking efficiency was evaluated as

$\begin{aligned} \text { Stacking efficiency }= & E_{\text {stacked supermolecule }}-\left(E_{\text {monomer }}\right. \\ & \times \text { no of monomers })\end{aligned}$

Complete geometry optimization of stacked supermolecule is not feasible by ab initio calculations. Stacking efficiency has been computed by single-point calculation of energy of stacked supermolecule. BSSE estimate was obtained using Boys Bernardi counterpoise correction (Boys and Bernardi 1970) method.

After understanding the characteristics required in cyclic peptide for self-assemblage and assessing feasibility of existence of self-assembled form, its usage as drug delivery system was considered. Drugs that cannot be delivered orally were considered for carriage. A model of solvated drug being carried was prepared. First the drug was optimized in gas phase by ab initio calculations. After completely optimizing drug Gentamicin and self-aggregated carrier that is trimer of (ala) ${ }_{12}$ in gas phase; the selfaggregated carrier was filled with water molecules using Soak option of Impact module (Impact 2010) from Maestro (Schrodinger 2009). The drug was then manually docked in soaked carrier displacing water molecules. Resulting model of solvated Gentamicin carriage by (ala) ${ }_{12}$ trimer was then subjected to ab initio molecular orbital geometry optimization by Berny's algorithm. This allows water molecules to properly orient mediating interaction between drug and carrier.

Conformational reorganization of drug, nanotube and water molecules was then calculated. Overall stabilization of the system was evaluated along with reorganization required in nanotube and its contents. Low reorganization indicates mutual suitability. Feasibility of usage of selfaggregated cyclic peptidomimetic system as drug delivery system was thus predicted.

\section{Results and discussion}

We have first studied some peptide and peptidomimetic systems in their monomeric form to understand change in characteristics with size and type of backbone and substituents. Figure 3 depicts optimized conformations for different monomers with peptide or peptidomimetic backbone. All monomers containing peptide backbone and same number of residues show same inner diameter of 

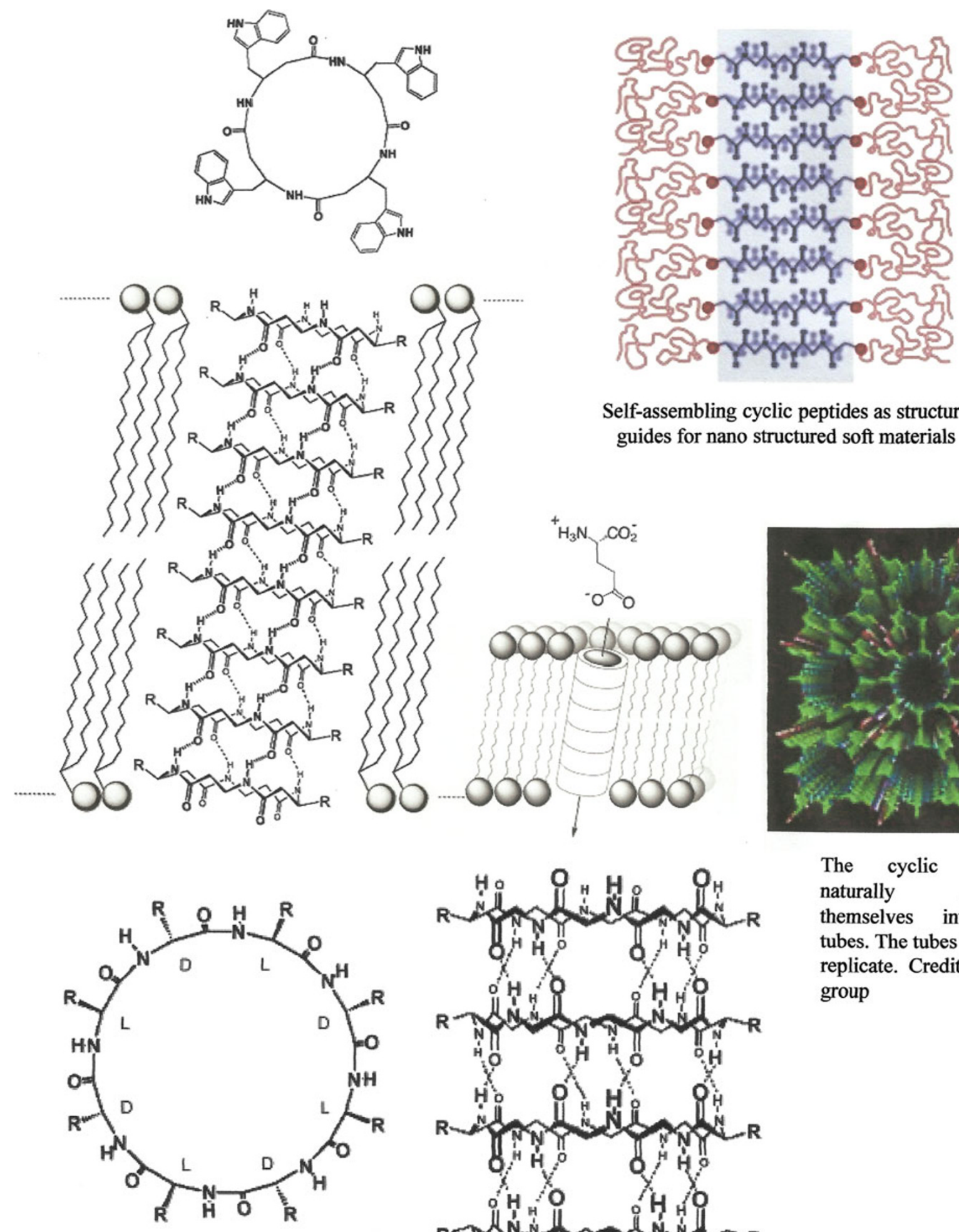

Self-assembling cyclic peptides as structure guides for nano structured soft materials
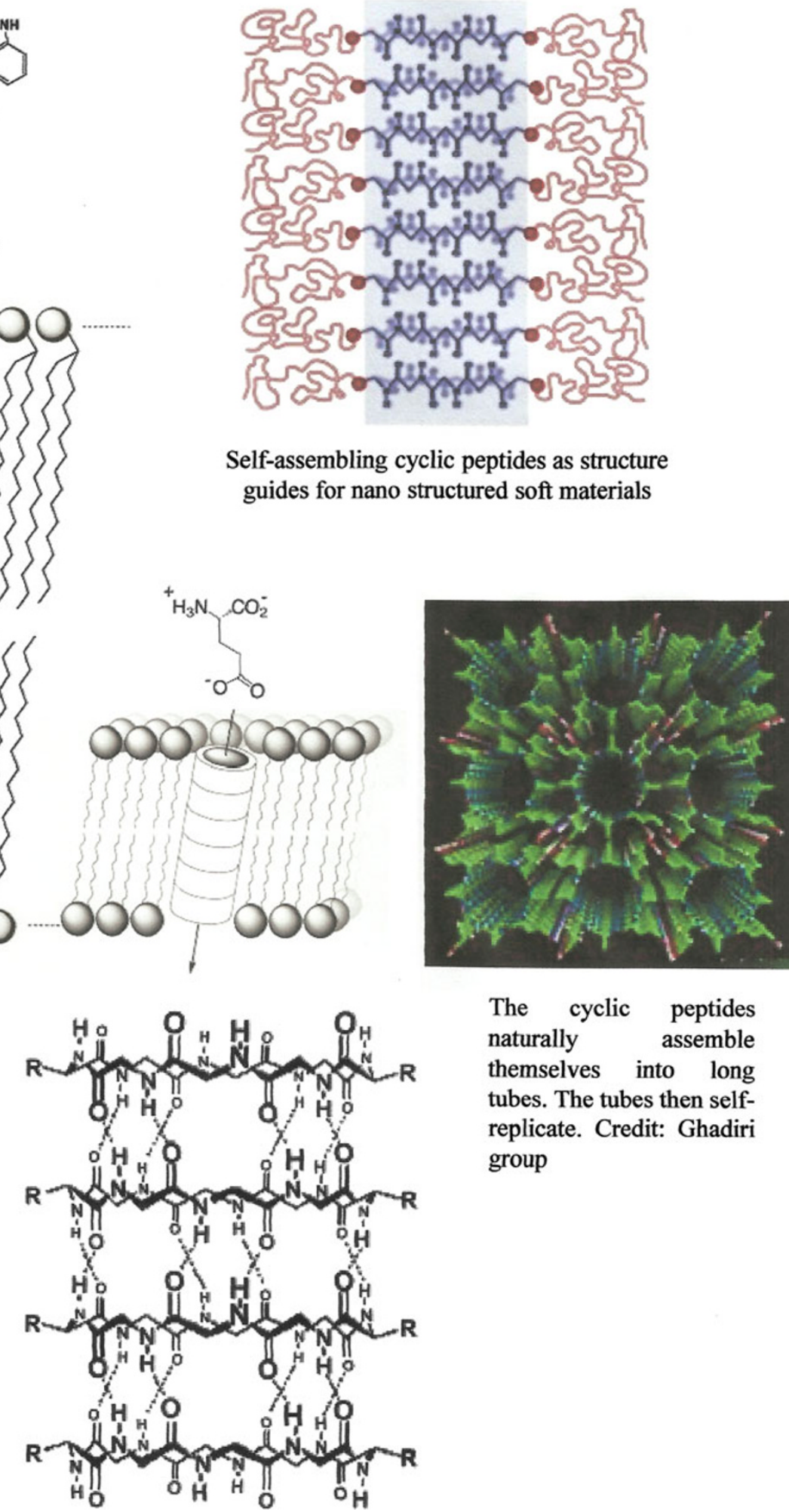

The cyclic peptides naturally assemble themselves into long tubes. The tubes then selfreplicate. Credit: Ghadiri group

Fig. 1 Some applications of self-aggregating cyclic peptides 
$12.9 \AA$. Outer dimensions obviously depend on substituent. (Ala) 12 monomer with $\mathrm{CH}_{2} \mathrm{NH}$ backbone and $\mathrm{CO}-\mathrm{O}-$ backbone shows inner diameters of 10.1 and $10.9 \AA$, respectively. The dependence of pore size on ring size is obvious. Cyclic peptides with less than six substituents cannot be used for practical drug carriage purposes. The type of backbone and the size of backbone thus determine the diameter of the pore formed by aggregated form of these cyclic systems. This study concentrates on ring systems with at least eight substituents so that their practical usage can be investigated.
Dimerization tendencies of various monomers judged by intermolecular interaction calculations are shown in Figs. 4, 5. The interaction energy has been calculated after complete optimization of dimer. (Ala) ${ }_{12}$ system with peptide backbone shows good dimerization tendency when both monomers are in eclipsed orientation as well as when both the monomers are in staggered orientation (c.f. Fig. 4). Staggered orientation is preferred due to obvious alleviation of repulsive interactions between alanine substituents of one monomer with that of the other. (Val) 12 system does not show any dimerization tendency even in
Fig. 2 Self-aggregating cyclic peptides as artificial membranes and channels
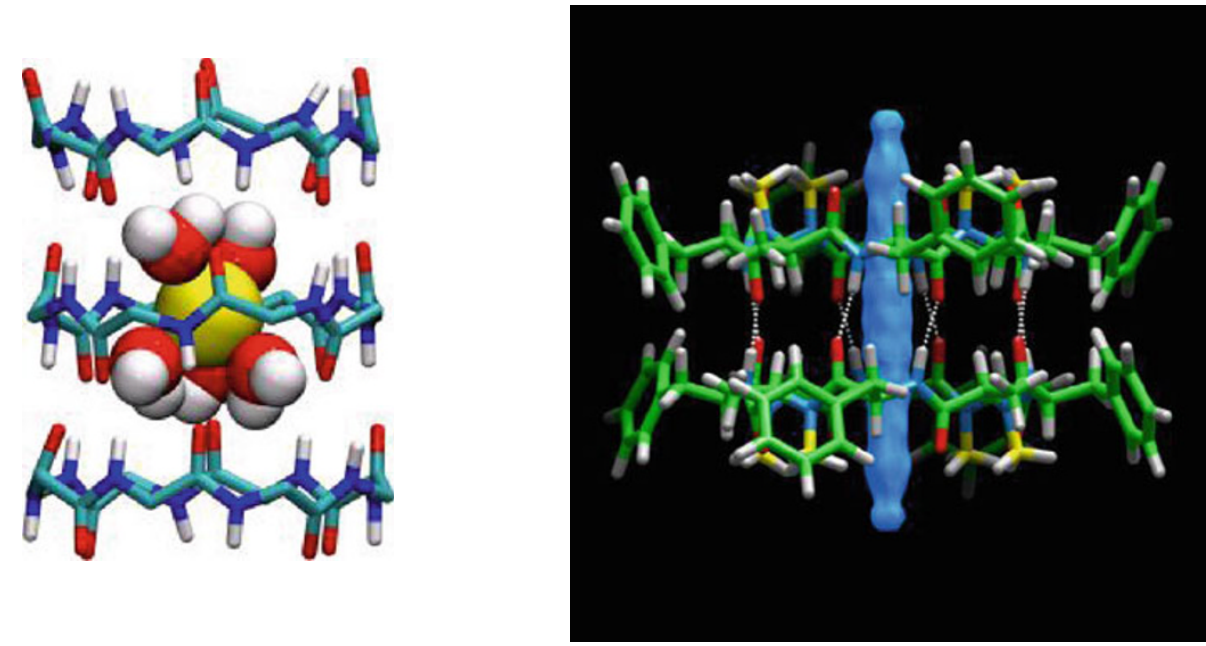

Conduction of hydrated sodium ion through artificial channel.
Water wire: Conduction of water through hydrophobic channel

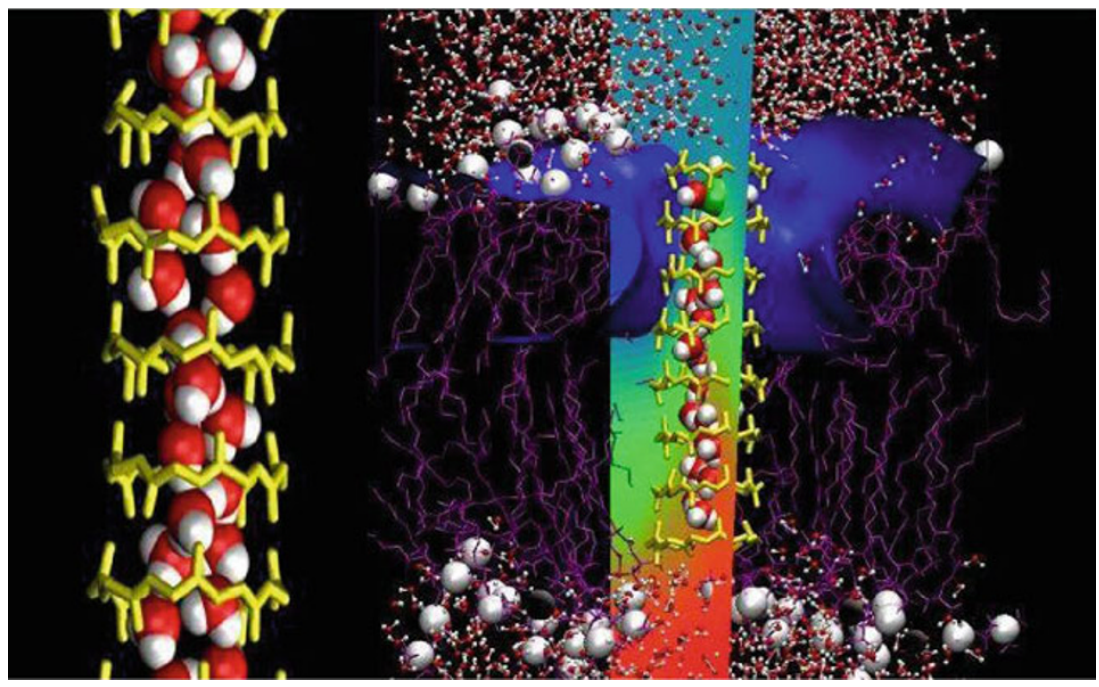

e 8,10 and 12 cyclic peptide subunits form tubular structures with internal pore dimensions in the range of $7-13 \AA$.

e They serve as conduit for water.

e They can function as size selective ion channel.

e They can be used to transport biologically relevant molecules like glucose across cell membranes. 
staggered orientation due to the size of the substituents which cause repulsion and steric hindrances. (Gln-Ala) 6 system also shows appreciable dimerization tendency as the glutamine residues of monomers can interact by $\mathrm{H}$-bonding and electrostatic interactions (c.f. Fig. 5). Steric problem is alleviated due to alternating alanine residues. A twisted arrangement of monomers is preferred in this case. Next we have considered dimerization tendency of monomers containing peptidomimetic backbone. In this case $(\mathrm{Ala})_{12}$ system has been studied to avoid any steric problems. This will enable us understand most suitable backbone for self-aggregation of such systems. (Ala) 12 with $\mathrm{CH}_{2} \mathrm{NH}$ backbone (c.f. Fig. 6) does not show any possibility of self-aggregation due to highly hydrophobic backbone. However, the effect of solvent polarity on selfaggregation tendency remains to be studied. It is unlikely
Fig. 3 Effect of backbone on size of cyclic system

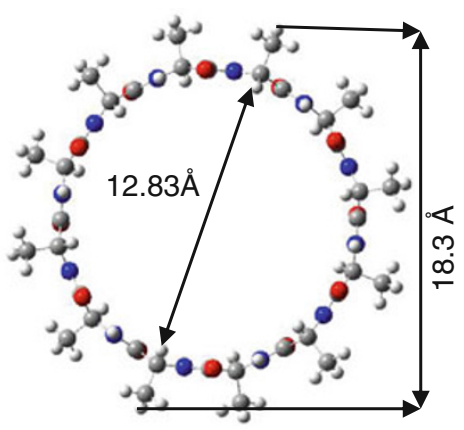

System-monomer(Ala) ${ }_{12}$ Back bone- Peptide linkage

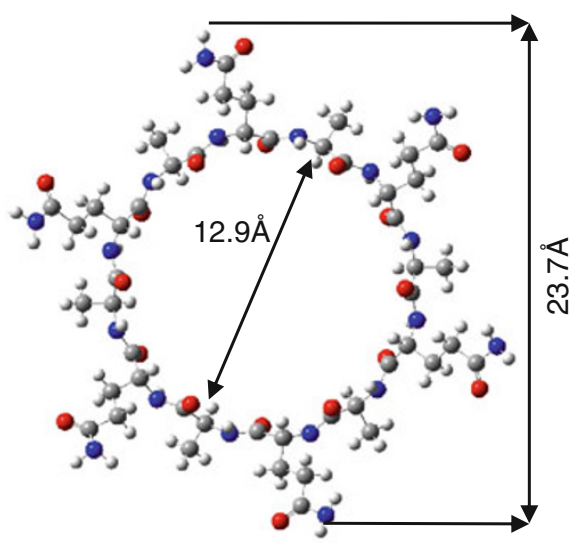

System-Monomer(Gln-Ala-Gln-Ala) ${ }_{3}$ Backbone- Peptide linkage

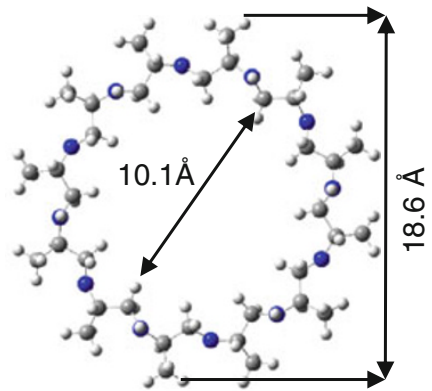

System-Monomer(Ala)12 Backbone $-\mathrm{CH}_{2}-\mathrm{NH}$ - linkage

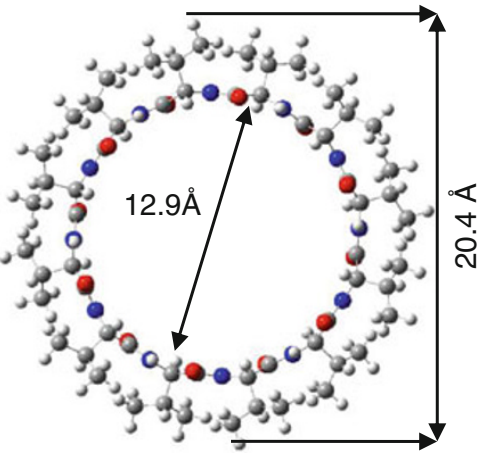

System-monomer $(\mathrm{Val})_{12}$ Back bone- Peptide linkage

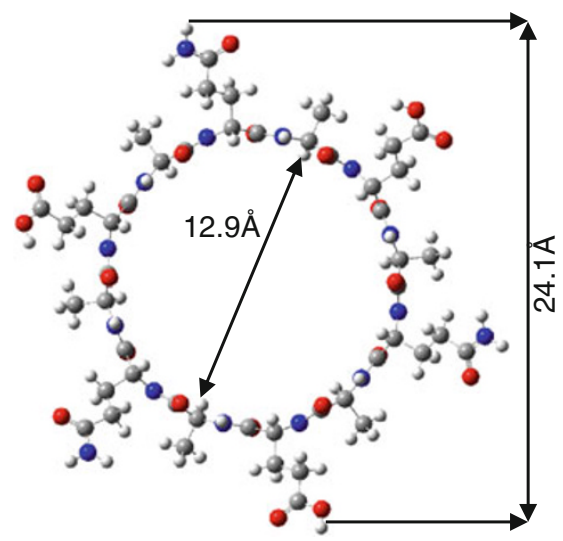

System-Monomer(Gln-Ala-Glu-Ala)

Backbone- Peptide linkage

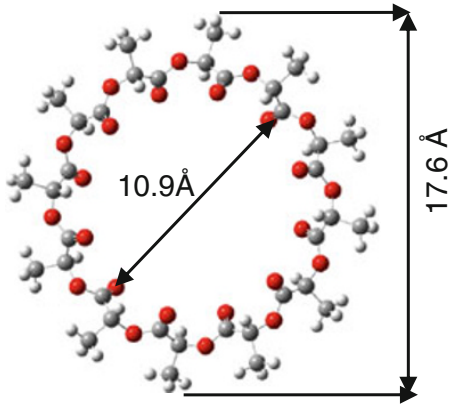

System-Monomer(Ala)12

Backbone (-CO-O-) linkage

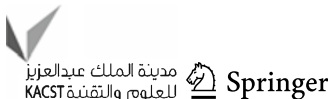


Fig. 4 Effect of hydrophobic substituents on dimerization tendency of cyclic peptides

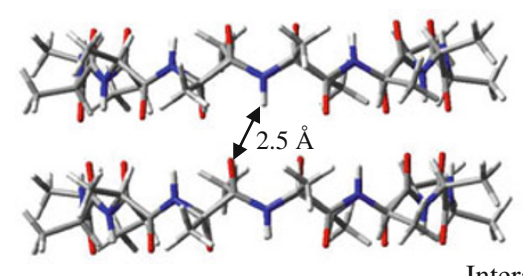

Eclipsed orientation Side view Interaction energy $=-75.58 \mathrm{kCal} / \mathrm{mol}$ Dimer of cyclic (Ala) 12 system with peptide backbone

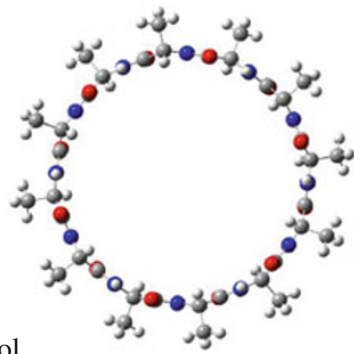

Top view

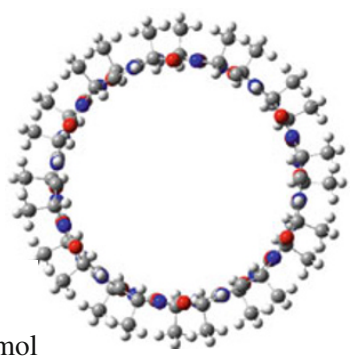

Interaction energy $=-84.50 \mathrm{kCal} / \mathrm{mol}$

Dimer of cyclic (Ala) ${ }_{12}$ system with peptide linkage

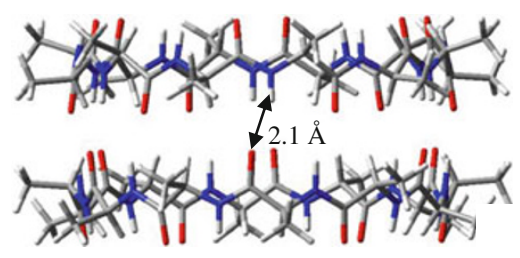

Side view
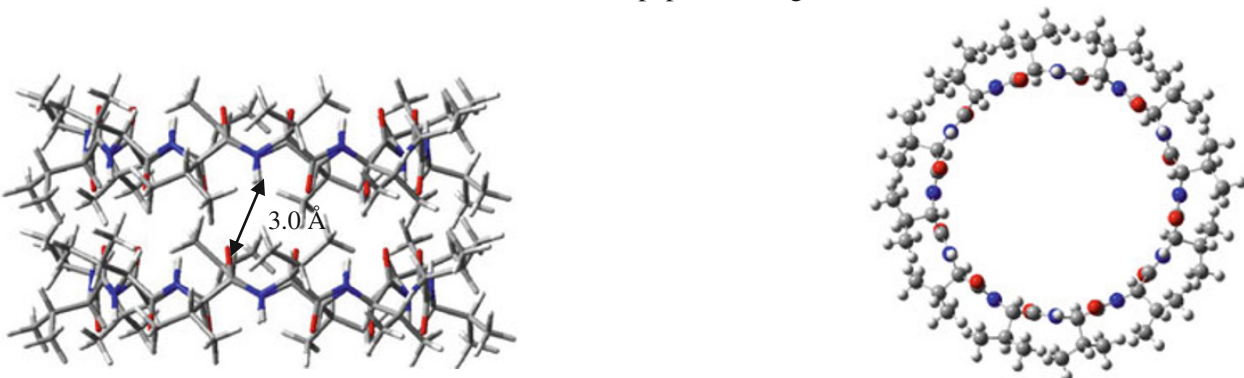

Top view

Interaction energy $=+133.54 \mathrm{kCal} / \mathrm{mol}$

Dimer of cyclic $(\mathrm{Val})_{12}$ system with peptide linkage

No dimerization tendency due to repulsive interaction that solvent molecules may squeeze in between rings of cyclic peptide but their presence inside pore may lead to enhanced attractive interactions. This system is ideal for enhancing levodopa bioavailability in monomeric form as suggested by us in our previous work (Banerjee and Yadav 2011). (Ala) ${ }_{12}$ system with (CO-O-) backbone shows only little tendency to self-aggregate as the backbone contains enhanced flexibility and tends to pucker in a way not suitable for efficient self-aggregation. These results are also depicted in Fig. 6.

Self-aggregation tendency of such systems is thus a close interplay of substituent type and backbone type. It is also dependent on overall size of the system (i.e. inner diameter of cyclic system). However, in this study size of the system studied is suitable for application under consideration. Cyclic peptides with less than six amino acids can practically not be used for carriage of anything other than a small ion.

(Ala) 12 system was chosen to study tubular formation by self-aggregation. (Ala) 12 system should give rise to tubular structure that is largely hydrophobic and inert from inside (Jishi et al. 1998) as well as from outside. Such an aggregated system may be used as drug delivery system to deliver contents inside cell at target.

Self-aggregation in (ala) 12 system was studied by gradually increasing number of monomers and evaluating interaction energy until enhanced tendency for aggregation was being observed (i.e. until interaction energy was increasingly negative). As the aggregated system becomes larger, artifacts due to methodology tend to creep in. 


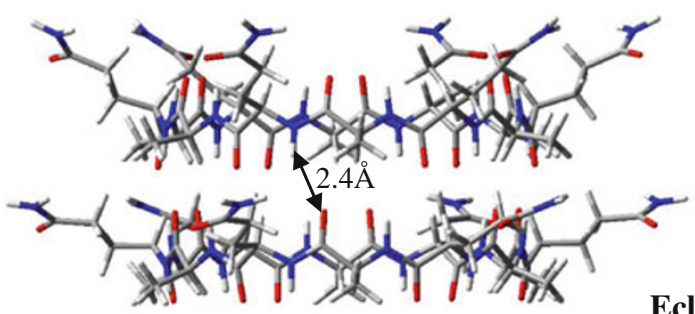

Eclipsed orientation

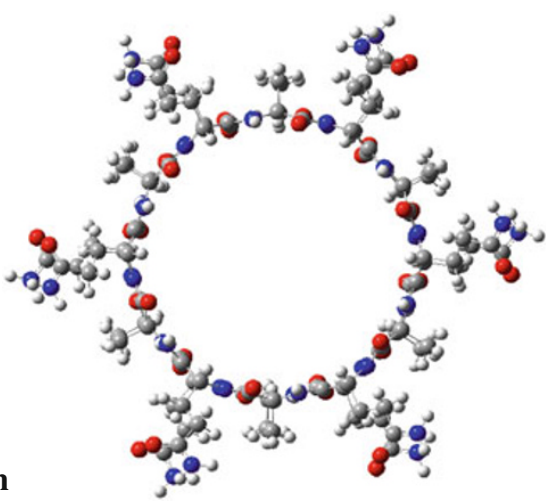

Side view

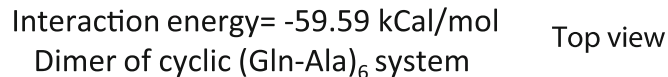

with (-CO-NH-) linkage

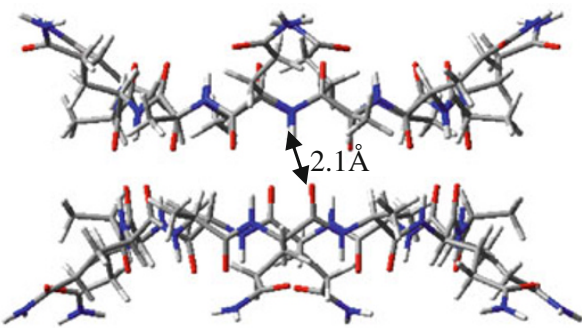

Staggered orientation

Interaction energy $=-76.61 \mathrm{kCal} / \mathrm{mol}$

Side view

Dimer of cyclic (Gln-Ala) ${ }_{6}$ system

with (-CO-NH-) linkage

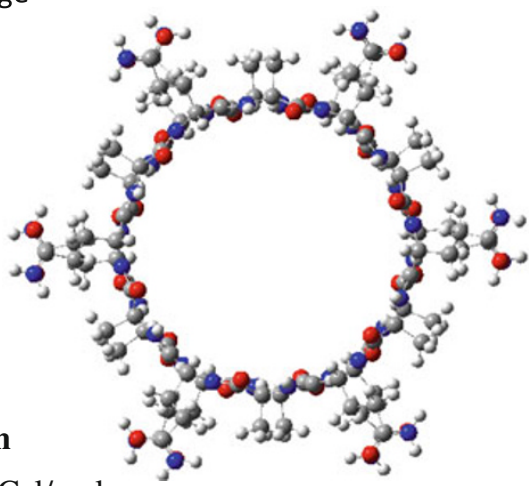

Top view

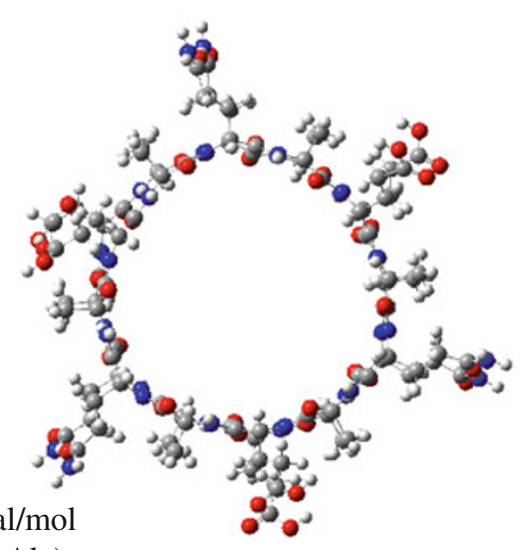

Interaction energy $=-82.39 \mathrm{kCal} / \mathrm{mol}$

Dimer of cyclic (Glu-Ala-Gln-Ala) 3 system with (-CO-NH-) linkage

Top view

Side view

Fig. 5 Effect of polar substituents on dimerization tendency of cyclic peptides

Therefore, stacking efficiency has been studied at larger basis set as well; evaluating basis set superimposition error (BSSE) simultaneously each time until computational facilities at hand could support ab initio HF calculations. ${ }^{1}$ Results for the same are collected in Table 1. Some of the

\footnotetext{
${ }^{1}$ When memory requirement crosses $2 \mathrm{~GB}$, it is not possible to compute using 32 bit machine.
}

results are depicted in Fig. 7. An efficient aggregation of 14 monomer units was observed after which interaction starts to decrease. Therefore, a small hydrophobic substituent in a cyclic peptide allows nanotube formation of diameter $\sim 13 \AA$ and length $71-75 \AA$. This length is sufficient enough to allow usage of these systems as drug delivery systems. The optimum distance between two stacked rings is between 2.6 and $3.1 \AA$. This is the nearest 


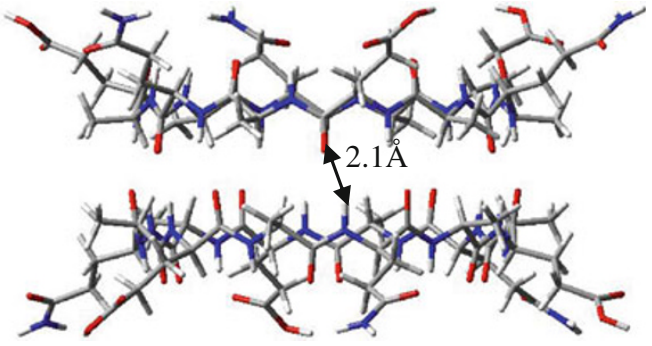

Side view
Staggered orientation Interaction energy $=-76.69 \mathrm{kCal} / \mathrm{mol}$ Dimer of cyclic (Glu-Ala-Gln-Ala) system with (-CO-NH-) linkage

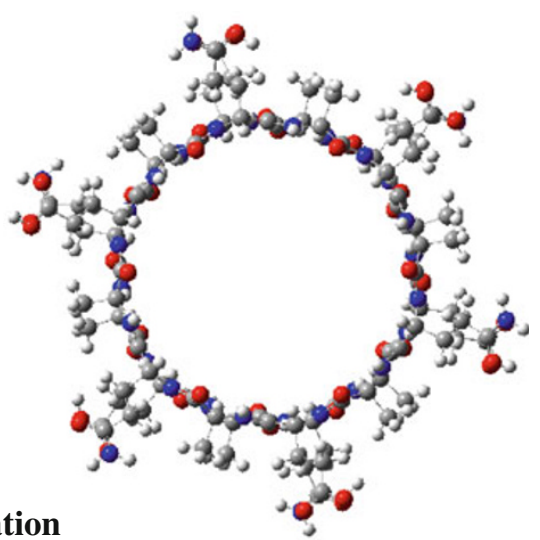

Top view

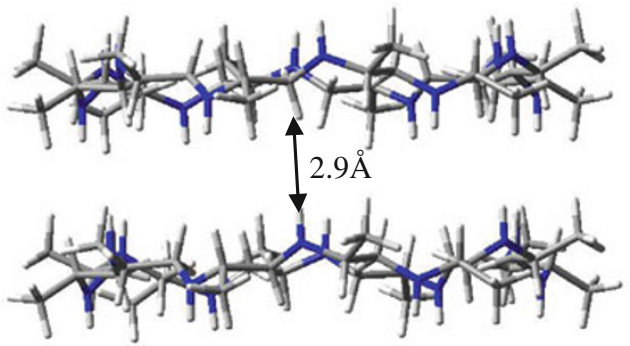

Side view

Repulsive Interaction

Dimer of cyclic (Ala) ${ }_{12}$ system with $\left(-\mathrm{CH}_{2}-\mathrm{NH}-\right)$ linkage No dimerization tendency with non polar backbone

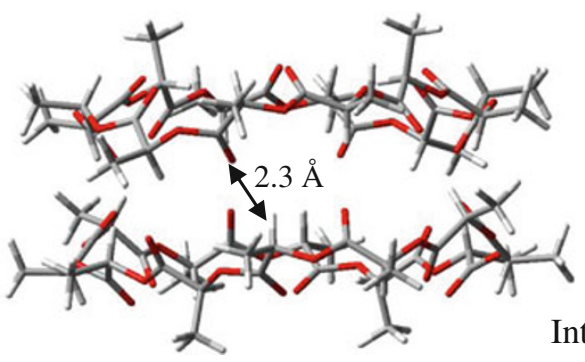

Side view
Interaction energy $=-24.49 \mathrm{kCal} / \mathrm{mol}$ Dimer of cyclic (Ala) ${ }_{12}$ system with (-CO-O-) linkage

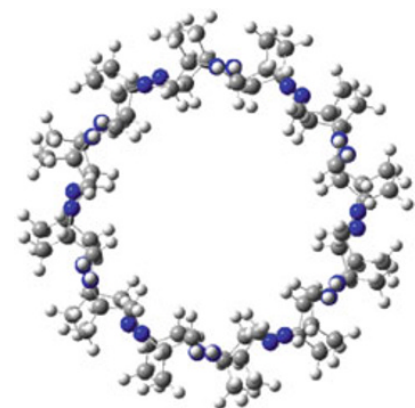

Top view

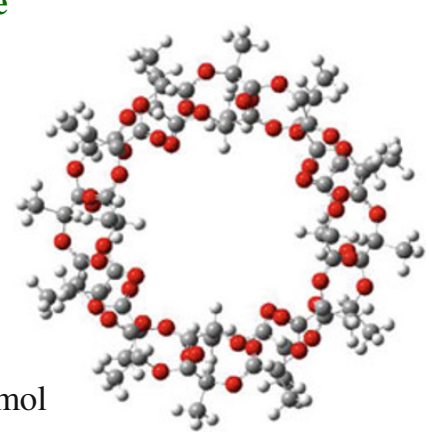

Top view

Fig. 6 Effect of backbone on dimerization tendency of cyclic peptides

distance between carbonyl of one backbone and -NH- of the adjoining monomer backbone.

The length to width ratio of tubular structure formed could be an important parameter in judging the strength and stability of nanotube formed similar to aspect ratio for fibers. To investigate length to width ratio for different systems for comparison we have studied (ala) ${ }_{10}$ system also. Results for $(\mathrm{ala})_{10}$ are shown in Fig. 8. For (ala) $)_{12}$ length to diameter ratio predicted is 4 as compared with a value of 3 for (ala) $)_{10}$ system. Extrapolation of these results predicts a value of 1 for (ala) $)_{6}$. (Glu-ala-gln-ala) ${ }_{n}$ system has been extensively prepared and studied by Ghadiri et al. Self-aggregation has been observed only when $n=2-4$ (Miyamoto et al. 1996).

If cyclic system is too small, efficient aggregation cannot be observed due to strain in backbone and if it is too 
Table 1 Self-assemblage tendency in (Ala) ${ }_{12}$ and (Ala) ${ }_{10}$ systems

\begin{tabular}{|c|c|c|c|c|c|c|c|}
\hline \multirow{4}{*}{$\begin{array}{l}\text { Number of monomer } \\
\text { units stacked }\end{array}$} & \multicolumn{6}{|c|}{$(\text { Ala })_{12}$ system } & \multirow{4}{*}{$\begin{array}{l}(\text { Ala })_{10} \text { system } \\
\text { Int. energy }(\mathrm{Ala})_{10} \\
\text { STO-3G }(\mathrm{kCal} / \mathrm{mol})\end{array}$} \\
\hline & \multicolumn{6}{|c|}{ Interaction energy (in $\mathrm{kCal} / \mathrm{mol}$ ) } & \\
\hline & \multicolumn{3}{|l|}{ STO-3G } & \multicolumn{3}{|l|}{$6-31 \mathrm{G}$} & \\
\hline & $\begin{array}{l}\text { Without } \\
\text { BSSE }\end{array}$ & $\begin{array}{l}\text { With } \\
\text { BSSE }\end{array}$ & $\begin{array}{l}\text { Amount of } \\
\text { BSSE correction }\end{array}$ & $\begin{array}{l}\text { Without } \\
\text { BSSE }\end{array}$ & $\begin{array}{l}\text { With } \\
\text { BSSE }\end{array}$ & $\begin{array}{l}\text { Amount of } \\
\text { BSSE correction }\end{array}$ & \\
\hline 2 & -14.24 & -8.46 & 5.78 & $\begin{array}{l}-45.67 \\
-75.58 \\
\text { (after opt.) }\end{array}$ & -34.36 & 11.31 & -17.68 \\
\hline 3 & -28.81 & -21.18 & 7.65 & $\begin{array}{l}-90.94 \\
-136.82 \\
\text { (after opt.) }\end{array}$ & -68.56 & 22.38 & -27.28 \\
\hline 4 & -47.19 & -37.58 & 9.61 & -140.08 & -106.13 & 33.95 & -42.46 \\
\hline 5 & -57.19 & -42.23 & 14.96 & -176.00 & -138.76 & 37.24 & -56.06 \\
\hline 6 & -54.03 & -35.93 & 18.10 & -229.63 & - & - & -69.34 \\
\hline 7 & -88.36 & - & - & -278.44 & - & - & -83.44 \\
\hline 8 & -107.57 & - & - & -333.30 & - & - & -97.14 \\
\hline 9 & -114.48 & - & - & - & - & - & -134.37 \\
\hline 10 & -129.09 & - & - & - & - & - & -125.76 \\
\hline 11 & -158.23 & - & - & - & - & - & -139.87 \\
\hline 12 & -162.74 & - & - & - & - & - & -170.16 \\
\hline 13 & -176.40 & - & - & - & - & - & -167.55 \\
\hline 14 & -236.00 & - & - & - & - & - & -175.86 \\
\hline 15 & -183.10 & - & - & - & - & - & -182.30 \\
\hline
\end{tabular}

large flexibility introduced in backbone does not allow efficient self-aggregation. These results are in agreement with our theoretical predictions.

Some natural peptides of diverse microbial origin possess the ability to self-aggregate at lipid phase and form trans membrane channels across lipid bilayers. Such peptides have interesting potential to be used as artificial membranes. However, the design and synthesis of artificial system is not an easy task. Considering work in progress by several groups along these lines, we have explored the usage of self-aggregated cyclic peptides as drug delivery systems. Drugs with intracellular targets show poor bioavailability. Some may lead to toxic effects when taken orally. In such cases a drug delivery system may be used to reduce toxicity and enhance therapeutic index. Carriage of antibiotic gentamicin encapsulated in peptide tubular structure has been considered in this study. Gentamicin is an aminoglycosidic antibiotic used to protect us against a wide spectrum of bacteria gram positive as well as gram negative (Kadurugamuwa and Beveridge 1998). Its use is restricted to low doses due to accumulation of its residues in kidney (Cabanes et al. 1998). Delivery of gentamicin at target may reduce its harmful effects.

Chemical structure for gentamicin and its completely optimized conformation are shown in Fig. 9. A minimum length drug delivery system formed by (ala) 12 cyclic peptide was taken to encapsulate gentamicin. Desired amount of self-aggregation may be achieved by $\mathrm{pH}$ control (Rajagopal et al. 2009; Aggeli et al. 2003). Complex was then subjected to complete geometry optimization to understand reorganization in delivery system required to efficiently carry gentamicin and to understand whether interaction is strong enough to hold gentamicin until delivery at target. These results are also shown in Fig. 9. Reorganizations required in carrier as well as drug are both small (carrier reorganization $=1.07 \mathrm{kCal} / \mathrm{mol}$, drug reorganization $=0.46 \mathrm{kCal} / \mathrm{mol}$ ) facilitating unhindered carriage of drug. Overall interaction energy is also reasonable to hold it until delivery at target such that premature expulsion of drug will be avoided. Release of drug at target may be natural by passive diffusion or by enzymatic disintegration of peptide carrier. 


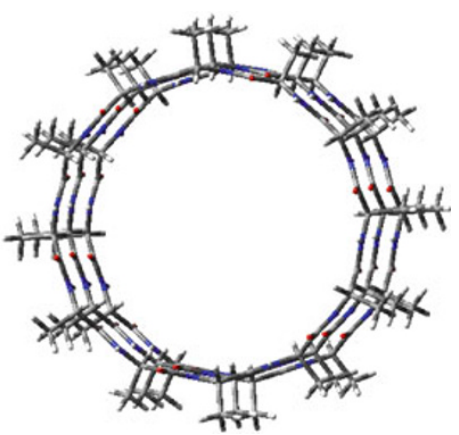

3 monomer units stacked Int. energy $=-28.81 \mathrm{kCal} / \mathrm{mol}$

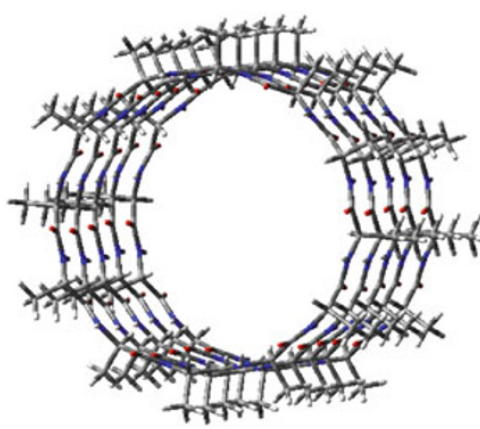

5 monomer units stacked Int. energy $=-57.19 \mathrm{kCal} / \mathrm{mol}$

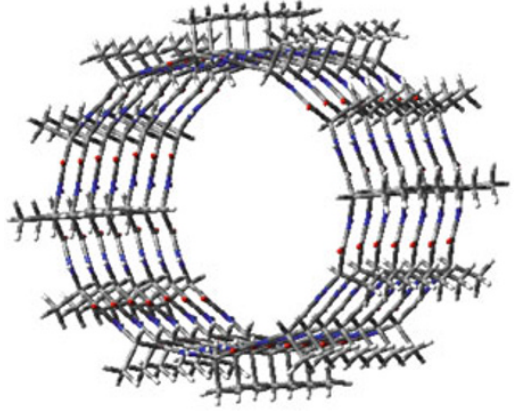

7 monomer units stacked Interaction energy $=-88.36 \mathrm{kCal} / \mathrm{mol}$

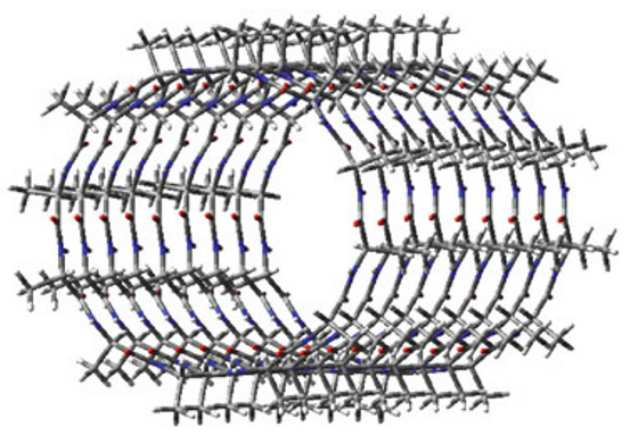

9 monomer units stacked

Interaction energy $=-114.48 \mathrm{kCal} / \mathrm{mol}$

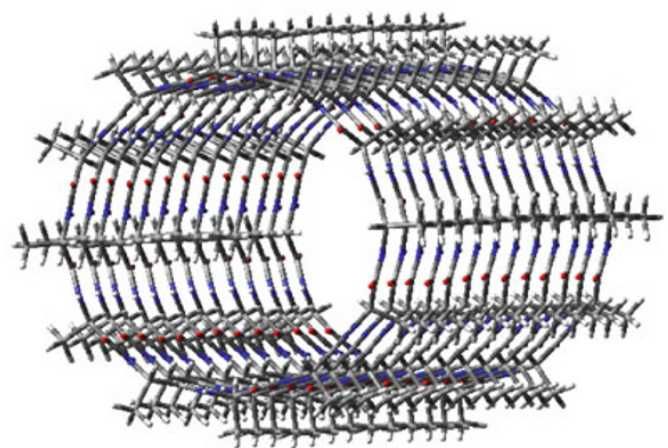

13 monomer units stacked Interaction energy $=-176.40 \mathrm{kCal} / \mathrm{mol}$

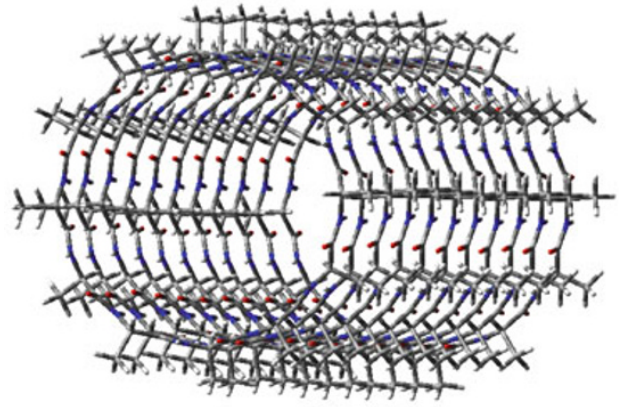

11 monomer units stacked Interaction energy $=-158.23 \mathrm{kCal} / \mathrm{mol}$

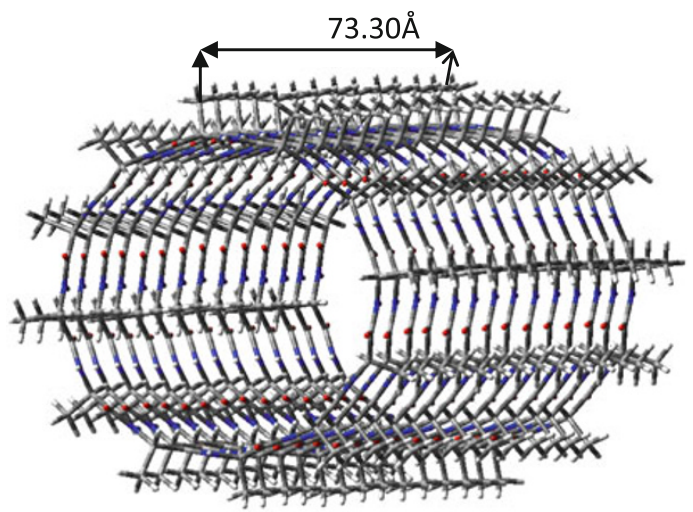

14 monomer units stacked Interaction energy $=-236.00 \mathrm{kCal} / \mathrm{mol}$

Fig. 7 Self-aggregation in (Ala) $)_{12}$ system

Further, to simulate more realistically we have taken drug in solvated form. Again carrier and solvated drug complex have been completely optimized. Water molecules also orient to give maximum stabilization to complex. Results for the same are depicted in Fig. 10. For solvated drug carriage also results indicate low reorganization and appropriate carriage efficiency. 


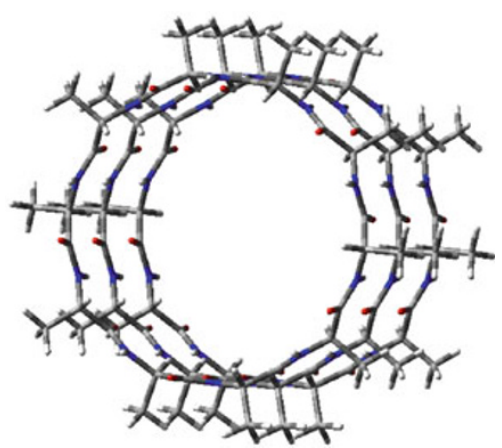

3 monomer units stacked Interaction energy $=-27.28 \mathrm{kCal} / \mathrm{mol}$

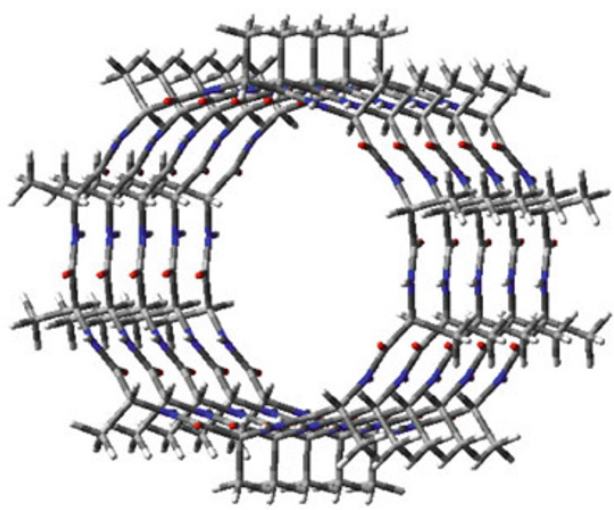

5 monomer units stacked Interaction energy $=-56.06 \mathrm{kCal} / \mathrm{mol}$

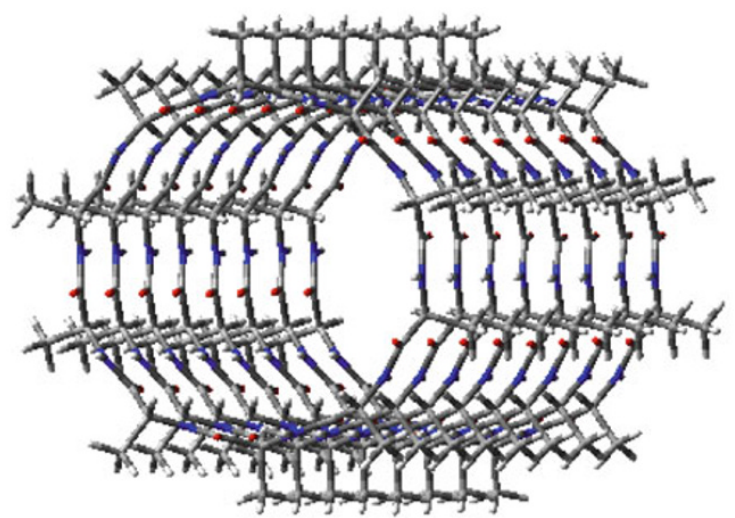

8 monomer units stacked

Interaction energy $=-97.14 \mathrm{kCal} / \mathrm{mol}$

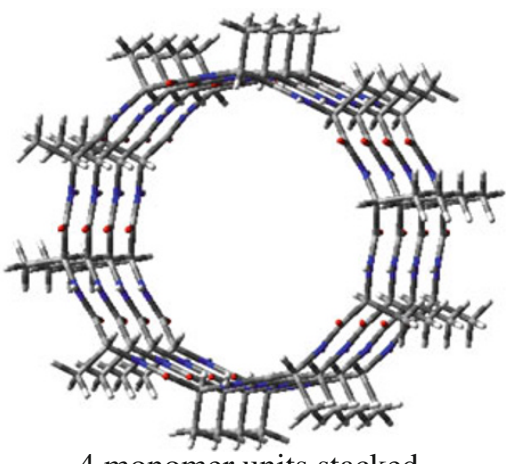

4 monomer units stacked Interaction energy $=-42.46 \mathrm{kCal} / \mathrm{mol}$

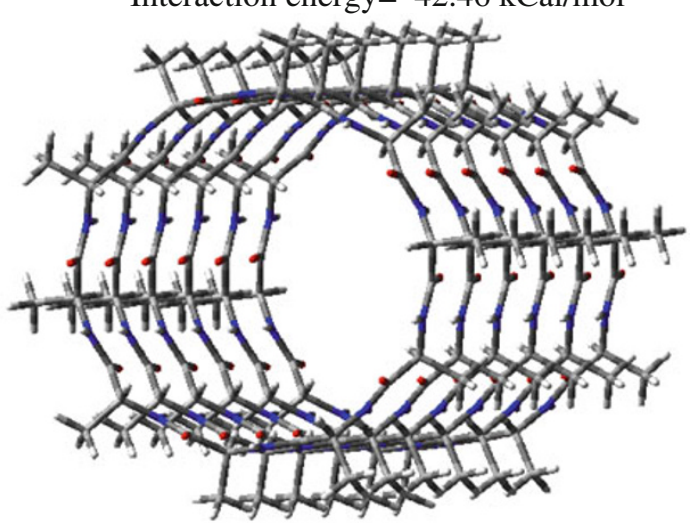

6 monomer units stacked Interaction energy $=-69.34 \mathrm{kCal} / \mathrm{mol}$

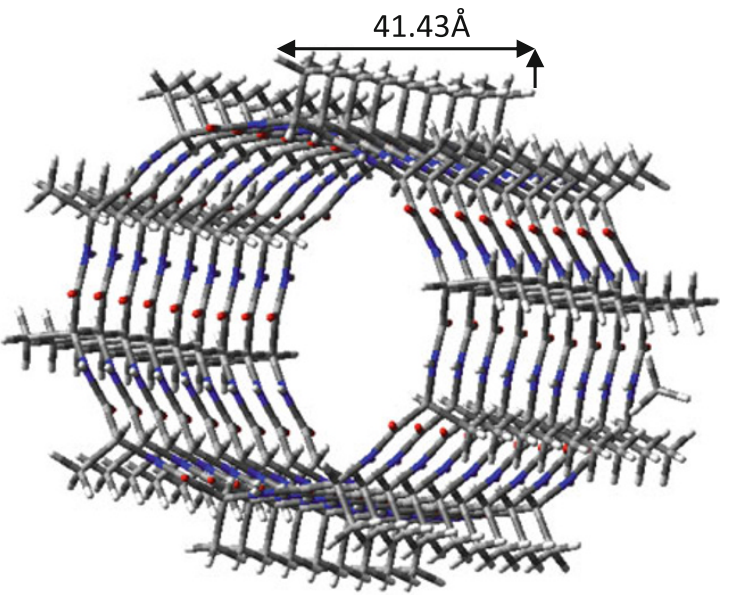

9 monomer units stacked Interaction energy $=-134.37 \mathrm{kCal} / \mathrm{mol}$

Fig. 8 Self-aggregation in (Ala) $)_{10}$ system

\section{Concluding remarks}

Overall study indicates that self-assembled cyclic peptides can be used in drug delivery systems to enhance bioavailability of certain drugs acting intracellularly.

Following inferences are drawn from this study:
1. In self-aggregating cyclic systems the type of backbone and size of backbone determines the diameter of pore formed.

2. Flat cyclic systems with small substituents favoring intermolecular H-bonding show appreciable selfassemblage tendency. 
<smiles>CCNC(C)[C@@H]1CC[C@@H](N)[C@H](O[C@@H]2[C@@H](N)C[C@@H](N)[C@H](O[C@@H]3OC[C@](C)(O)[C@H](NC)[C@H]3O)[C@H]2O)O1</smiles>

(a)

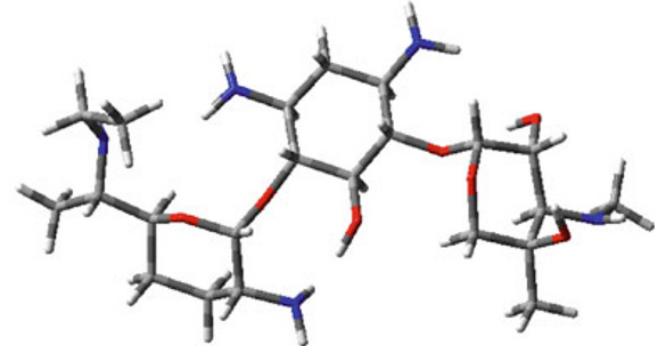

(b)

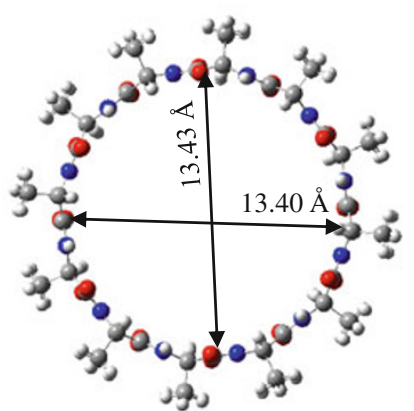

Top veiw

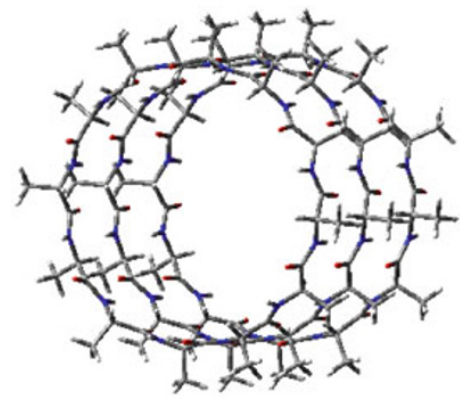

(c)

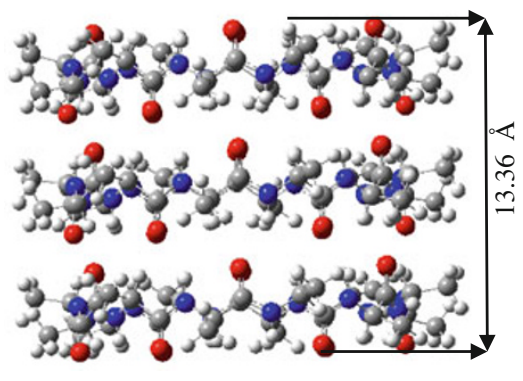

Side veiw

Interaction energy $=-136.82 \mathrm{kCal} / \mathrm{mol}$

Trimer of cyclic (Ala) ${ }_{12}$ system with (-CO-NH-) linkage

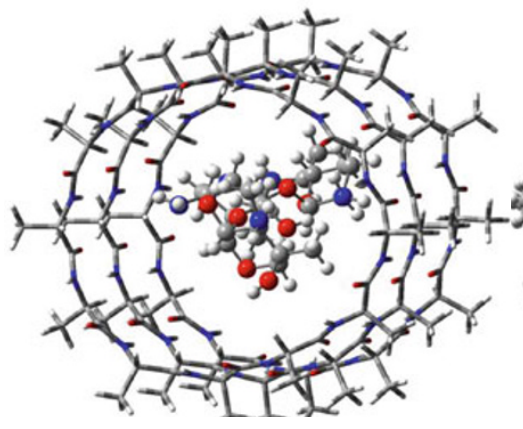

(d)

Electrostatic gain $=-8.72 \mathrm{kCal} / \mathrm{mol}$ $($ Carrier + Drug $)$ reorganization $=1.53 \mathrm{kCal} / \mathrm{mol}$ Overall stabilization $=-7.19 \mathrm{kCal} / \mathrm{mol}$

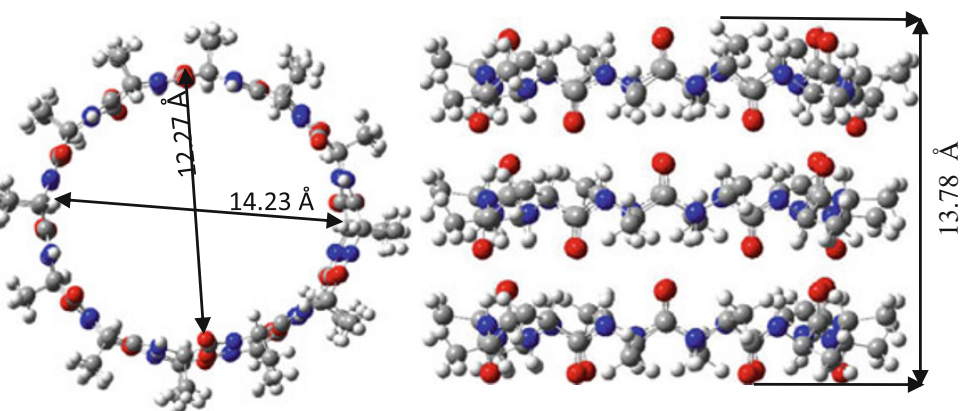

Side veiw

Top veiw

Carrier reorganization $=1.07 \mathrm{kCal} / \mathrm{mol}$

(e)

Fig. 9 a Chemical structure of gentamicin, b optimized gentamicin, c empty carrier. $\mathbf{d}$ complex, and e reorganized carrier

3. Highly hydrophobic backbone does not allow selfaggregation when studied in gas phase. Further work needs to be done to study stabilities in actual solvent environment.

4. Small hydrophobic substituent in a cyclic peptide allows nanotube formation of diameter $\sim 13 \AA$ and length 71-75 ̊. The optimum distance between two stacked rings is between 2.6 and $3.1 \AA$.

5. Trimer of cyclic peptide (ala) $)_{12}$ has been suggested as a carrier for solvated antibiotic gentamicin to avoid its side effects and enhance bioavailability at target and thus its therapeutic value. 
Fig. 10 Solvation of gentamicin and carriage of solvated gentamicin in a peptide delivery system
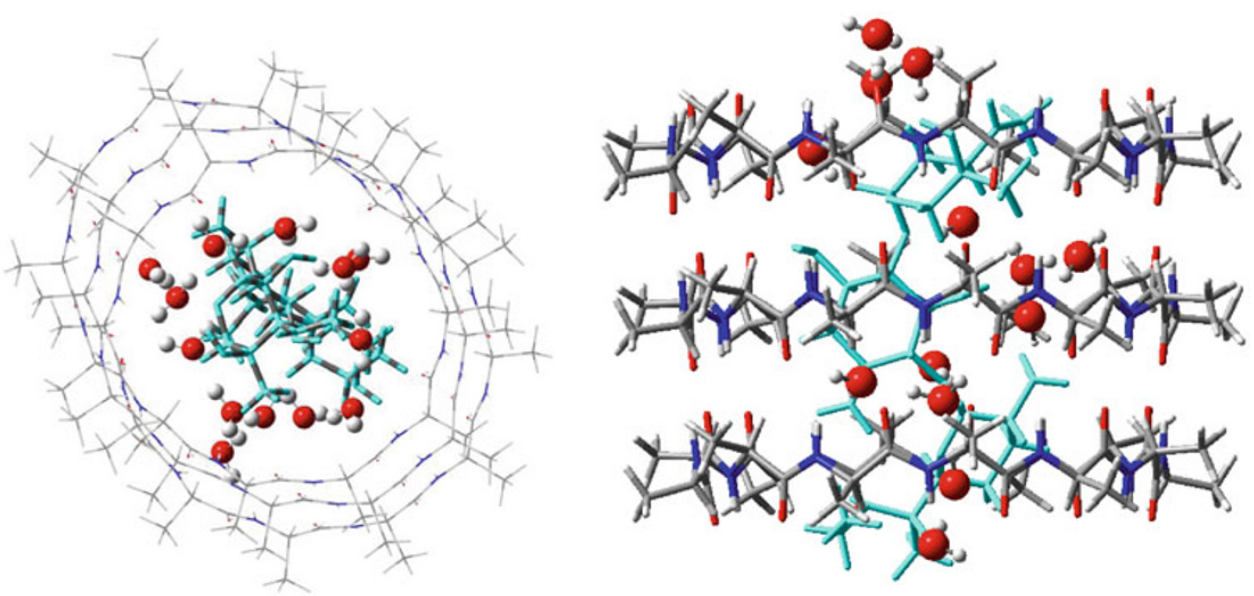

Interaction energy between carrier and solvated gentamicin $=-5.08 \mathrm{kCal} / \mathrm{mol}$

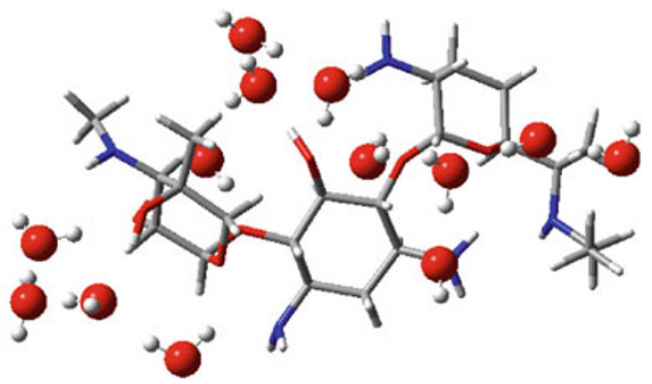

Solvation energy of gentamicin $=-97.89 \mathrm{kCal} / \mathrm{mol}$

Open Access This article is distributed under the terms of the Creative Commons Attribution License which permits any use, distribution, and reproduction in any medium, provided the original author(s) and the source are credited.

\section{References}

Aggeli A, Bell M, Carrick LM, Fishwick CWG, Harding R, Mawer PJ, Radford SE, Strong AE, Boden N (2003) pH as a trigger of peptide $\beta$-sheet assembly and reversible switching between nematic and isotropic phases. J Am Chem Soc 125:9619-9628

Ahn JM, Boyle NA, McDonald MT, Janda KD (2002) Peptidomimetics and peptide backbone modifications. Mini Rev Med Chem 2:463-473

Ajayan PM, Iijima S (1993) Capillarity-induced filling of carbon nanotubes. Nature (London) 361:333-334

Ajayan PM, Ebbesen TW, Ichihashi T, Iijima S, Tanigaki K, Hiura H (1993) Opening carbon nanotubes with oxygen and implications for filling. Nature (London) 362:522-524

Amorin M, Castedo L, Granja JR (2003) New cyclic peptide assemblies with hydrophobic cavities: The structural and thermodynamic basis of a new class of peptide nanotubes. J Am Chem Soc 125:2844-2845

Ashkenasy G, Ghadiri MR (2004) Boolean logic functions of a synthetic peptide network. J Am Chem Soc 126:11140-11141

Banerjee A, Yadav A (2011) In silico design of a peptidomimetic carrier for levodopa. Int J Biomed Sci 7:44-50
Boys SF, Bernardi F (1970) The calculation of small molecular interactions by the differences of separate total energies. Some procedures with reduced errors. Mol Phys 19:553-566

Brea RJ, Lopez-Deber MP, Castedo L, Granja JR (2006) Synthesis of $\omega$-(Hetero) arylalkynylated $\alpha$-amino acid by Sonogashira-type reactions in aqueous media. J Org Chem 71:7870-7873

Cabanes A, Reig F, Garcia-Auton JM (1998) Evaluation of free and liposome-encapsulated gentamycin intramuscular sustained release in rabbits. Res Vet Sci 61:213-217

Clark TD, Buehler LK, Ghadiri MR (1998a) Self assembling cyclic $\beta^{3}$-peptide nanotubes as artificial transmembrane ion channels. J Am Chem Soc 120:651-656

Clark TD, Buriak JM, Kobayashi K, Isler MP, McRee DE, Ghadiri MR (1998b) Cylindrical $\beta$-sheet peptide assemblies. J Am Chem Soc 120:8949-8962

Couet TD, Samuel JDJS, Kopyshev SS, Biesalski M (2005) Peptidepolymer hybrid nanotubes. Angew Chem Int Ed 44:3297-3301

Dennington II R, Keith T, Millam J, Eppinnett K, Hovell WL, Gilliand R (2003) Gaussview, Version 3.09, Semichem Inc, Shawnee Mission KS

Dujardin E, Ebbesen TW, Hiura H, Tanigaki K (1994) Capillarity and wetting of carbon nanotubes. Science 265:1850-1852

Ebbesen TW, Ajayan PM (1992) Large scale synthesis of carbon nanotubes. Nature (London) 358:220-221

Fernandez-Lopez S, Kim HS, Choi EC, Delgado M, Granja JR, Khasanov A, Krachenbuehl K, Long G, Weinberger DA, Wilcoxen KM, Ghadiri MR (2001) Antibacterial agents based on the cyclic D, L- $\alpha$-peptide architecture. Nature (London) 412: $452-455$ 
Frisch MJ, Trucks GW, Schlegel HB, Scuseria GE, Robb MA, Cheeseman JR, Montgomery JA Jr, Vreven T, Kudin KN, Burant JC, Millam JM, Iyengar SS, Tomasi J, Barone V, Mennucci B, Cossi M, Scalmani G, Rega N, Petersson GA, Nakatsuji H, Hada M, Ehara M, Toyota K, Fukuda R, Hasegawa J, Ishida M, Nakajima T, Honda Y, Kitao O, Nakai H, Klene M, Li X, Knox JE, Hratchian HP, Cross JB, Bakken V, Adamo C, Jaramillo J, Gomperts R, Stratmann RE, Yazyev O, Austin AJ, Cammi R, Pomelli C, Ochterski JW, Ayala PY, Morokuma K, Voth GA, Salvador P, Dannenberg JJ, Zakrzewski VG, Dapprich S, Daniels AD, Strain MC, Farkas O, Malick DK, Rabuck AD, Raghavachari K, Foresman JB, Ortiz JV, Cui Q, Baboul AG, Clifford S, Cioslowski J, Stefanov BB, Liu G, Liashenko A, Piskorz P, Komaromi I, Martin RL, Fox DJ, Keith T, Al-Laham MA, Peng CY, Nanayakkara A, Challacombe M, Gill PMW, Johnson B, Chen W, Wong MW, Gonzalez C, Pople JA (2004) Gaussian 03, Revision C.02, Gaussian, Inc., Wallingford

Ghadiri MR (1995) Self-assembled nanoscale tubular ensembles. Adv Mater 7:675-677

Ghadiri MR, Granja JR, Milligan RA, Mc Ree DE, Khazanovich N (1993) Self assembling organic nanotubes based on a cyclic peptide architecture. Nature (London) 366:324-326

Ghadiri MR, Granja JR, Buehler LK (1994) Artificial transmembrane ion channels from self assembling peptide nanotubes. Nature (London) 369:301-303

Ghadiri MR, Kobayashi K, Granja JR, Chadha RK, Mc Ree DE (1995) The structural and thermodynamic basis for the formation of selfassembled peptide nanotubes. Chem Int Ed Engl 34:93-95

Guerret-Piecourt C, Le Bouar Y, Lolseau A, Pascard H (1994) Relation between metal electronic structure and morphology of metal compounds inside carbon nanotubes. Nature (London) 372:761-764

Hamoda N, Sawada S, Oshiyama A (1992) New one-dimensional conductors: Graphitic microtubules. Phys Rev Lett 68:1579-1581

Harada A, Li J, Kamachi M (1993) Synthesis of a tubular polymer from threaded cyclodextrins. Nature (London) 364:516-517

Hartgerink JD, Granja JR, Milligan RA, Ghadiri MR (1996) Self assembling peptide nanotubes. J Am Chem Soc 118:43-50

Horne WS, Ashkenasy N, Ghadiri MR (2005) Modulating charge transfer through cyclic D, L $\alpha$-peptide self assembly. Chem Eur J 11:1137-1144

Ijima S (1991) Helical microtubules of graphitic carbon. Nature (London) 35:56-57

Impact, version 5.6, LLC, New York, NY, 2010

Jishi RA, Braier NC, White CT, Mintmire JW (1998) Peptide nanotubes: an inert environment. Phys Rev B 58:R16009-R16011

Jung G (1999) Combinatorial chemistry: synthesis, analysis, screening, Wiley-VCH Publication, Weinheim

Kadurugamuwa JL, Beveridge TJ (1998) Delivery of the nonmembrane permeative antibiotic Gentamicin into mammalian cells by using Shigella flexneri membrane vesicles. Antimicrob Agents chemother 42:1476-1483

Khazanovich N, Granja JR, Mc Ree DE, Milligan RA, Ghadiri MR (1994) Nanoscale tubular ensembles with specified internal diameters. Design of a self assembled nanotube with a $13 \AA$ pore. J Am Chem Soc 116:6011-6012

Kim HS, Hartgerink JD, Ghadiri MR (1998) Oriented self-assembly of cyclic peptide nanotubes in lipid membranes. J Chem Soc 120:4417-4424
Kobayashi K, Granja JR, Ghadiri MR (1995) $\beta$-sheet peptide architecture: Measuring the relative stability of parallel vs antiparallel $\beta$-sheets. Angew Chem Int Ed Engl 34:95-98

Leclair S, Baillargeon P, Skouta R, Gauthier D, Zhao Y, Dory YL (2004) Mirometer-sized hexagonal tubes self-assembled by a cyclic peptide in a liquid crystal. Angew Chem Int Ed 43: 264-270

Loiseau A, Pascard H (1996) Synthesis of long carbon nanotubes filled with $\mathrm{Se}, \mathrm{S}, \mathrm{Sb}$ and Ge by the arc method. Chem Phys Lett 256:246-252

Mintmire JW, Dunlap BI, White CT (1992) Are fullerene tubules metallic? Phys Rev Lett 68:631-634

Miyamoto Y, Louie SG, Cohan ML (1996) Chiral conductivities of nanotubes. Phys Rev Lett 76:2121-2124

Ortiz-Acevedo A, Xie H, Zorbas V, Sampson WM, Dalton AB, Baughman RH, Draper RK, Musselman IH, Dieckmann GR (2005) Diameter-selective solubilization of single-walled carbon nanotubes by reversible cyclic peptides. J Am Chem Soc 127: 9512-9517

Peng C, Schlegel HB (1994) Israel J Chem 33:449

Peng C, Ayala PY, Schlegel HB, Frisch MJ (1996) Using redundant internal coordinates to optimize equilibrium geometries and transition states. J Comput Chem 17:49-56

Raghavender US, Aravinda S, Shamala N, Rai KR, Balaram P (2009) Characterization of water wires inside hydrophobic tubular peptide structures. J Am Chem Soc 131(42):15130-15132

Rajagopal K, Lamm MS, Haines-Butterick LA, Pochan DJ, Schneider JP (2009) Tuning the $\mathrm{pH}$ responsiveness of $\beta$-hairpin peptide folding, Self-assembly and hydrogel material formation. Biomacromolecules 10:2619-2625

Saito R, Fujita M, Dresselhaus G, Dresselhaus MS (1992) Electron structure of graphane tubules based on $\mathrm{C}_{60}$. Phys Rev B 46: 1804-1811

Sanchez-Quesada J, Ghadiri MR, Bayley H, Braha O (2000) Cyclic peptides as molecular adapters for a pore-forming protein. J Am Chem Soc 122:11757-11766

Sanchez-Quesada J, Kim HS, Ghadiri (2001) A synthetic pore mediated transmembrane transport of glutamic acid. Angew Chem Int Ed 40(13):2503-2506

Schalley CA (2004) Elements for the construction of molecular devices: template effects and self assembly. J Phys Org Chem 17:967-972

Schnur JM (1993) Lipid tubules: a paradigm for molecularly engineered structures. Science 262:1669-1676

Schrodinger LLC (2009) Maestro, Schrodinger LLC, New York

Sloan J, Hammer J, Zwiefka-Sibley M, Green MLH (1998) The opening and filling of single walled carbon nanotubes (SWTs). Chem Commun (Cambridge), pp 347-348

Thess A, Lee R, Nikolaev P, Dai H, Petit P, Robert J, Xu E, Lee YH, Kim SG, Rinzler AG, Colbert DT, Scuseria GE, Tomanek D, Fischer JE, Smalley RE (1996) Crystalline ropes of metallic carbon nanotubes. Science 273:483-487

Tu RS, Tirrell M (2004) Bottom-up design of biomimetic assemblies. Adv Drug Del Rev 56(11):1537-1563

White CT, Robertson DH, Mintmire JW (1993) Helical and rotational symmetries of nanoscale graphitic tubules. Phys Rev B 47: $5485-5488$ 